\title{
Research on Strategies for Main Channel Construction of Ideological and Political Education of University Students at Present
}

\author{
Mingjun $\mathrm{Wu}^{1}$, Jibiao Zhang $^{1}$, Hebao Wang $^{1}$ \\ ${ }^{1}$ XingTai University, Xingtai, 054001, China
}

\begin{abstract}
Keywords: Ideological and political education of university students; Main channel construction;
\end{abstract} Strategy and method

\begin{abstract}
The ideological and political theory course carried in universities does not only undertake the task of advocating the Marxism, but also the heavy burden of leading the university students to build a correct life concept, value concept and world concept. At present, some achievements have been made in the ideological and political theory course in many aspects, but there are still many problems, which directly influence the construction and development of ideological and political theory course.
\end{abstract}

\section{Introduction}

At present, the ideological and political education theory course in university students is main approach to cultivate the ideological and moral consciousness of university students, which has a certain status in the university education. How to enrich the contents of ideological and political courses in universities is a main problem faced by various universities in China. In the process of carrying out the ideological and political theory course, there are many problems worth researching and discussing. Only by deepening understanding the shortcomings existing in the ideological and political theory course and continuously improving them can we really promote the construction and development of ideological and political theory course in universities.

\section{Main basis to establish ideological and political education of university students}

There are many ways and methods to carry out ideological and political education work of university students, the approaches for the ideological and political theory course are not only, but have deep realistic basis, historical basis and theoretical basis in various aspects. First, process of ideological and political education decides the importance of ideological and political education course. In the social level, the ideological and political education theory work of each level reflects the fundamental root pursued by the ruling class in each aspect, with quite a significant class character. In order to ensure that its ideology can have a certain ruling status, the ruling class needs to carry out various courses from various aspects to continuously strengthen its own ideology. In the process of university education, the ideological and political education is the central reflection of consciousness of ruling class, and is also the systematic education of the theory of Marxism. Second, the scientific and systematic ideological and political education contents require to continuously the ideological and political education to the students. From various aspects, the ideological concept of Marxism is a theoretical and scientific ideological consciousness, while some specific ideological consciousnesses cannot be reflected in the interpretation of other subjects, but must educate the university students systematically in terms of ideology from the connection of various aspects. To carry out the ideological and political education course, it is required to convey a series of theories of Marxism to the university students and help them establish a correct world concept. Third, from ancient times to now, China has always been emphasizing the education of traditional morality very much. Under the background of different periods, the education contents of "moral education" varied, but within various periods, people emphasize the "moral education" very much, and carry out the moral education work so that more people will receive the moral education. Therefore, the contemporary moral education workers should also attach great importance to the moral education 
work. There are many shortcomings in the traditional moral education, but combined with the modern moral education effectively, it can really promote the smooth implementation of moral education work.

\section{Problems faced in education and development of ideological and political education of university students}

\section{Excessive transformation of contents of teaching materials}

From various aspects, education means a series of processes, with all course contents mutually associated. The connection of ideological and political theory course is specifically reflected in the continuous transformation from the ideological and political education contents required for the course to the contents of teaching materials. In the contemporary times, some teachers of ideological and political education in China still adopt the traditional moral education course during teaching, and present the knowledge in the books to students completely. Some teachers have realized the importance of transformation of teaching material contents, but transform the teaching material contents to teaching contents, and this also cannot reach the fundamental purpose of education. It cannot reach the education objective, on the contrary, it will achieve an opposite effect. In addition, some teachers "transform" too much, although the initial purpose is to improve the teaching atmosphere of the class, there is a great gap between the teaching contents and course standard. Therefore, although the innovation of teaching method is quite important, it is also required to master the "degree" of innovation.

\section{Contradiction between teaching scientific research and teaching task}

With the rapid development of times, the university students are more open and active in thinking and ideologically, they have very strong participation awareness and competition awareness. This proposes higher requirements for the teachers of ideological and political education teachers and requires the ideological and political teachers to timely master the issues concerned by the students, propose the issues similar to these issues according to the students' concern and deeply discuss these issues, and such way of teaching is not limited to the book contents, but also deeply expands the teaching contents and some basic theoretical knowledge. It both emphasizes the combination of theoretical knowledge and practical knowledge, but also skillfully combines the historical knowledge with the realistic knowledge, not only achieving the teaching effect, but also arousing the students' strong interest in learning the ideological and political theory course. On the other hand, because in modern times, the Ministry of Education has greatly promoted the specific plan for the reform of ideological and political course, in order to further promote the development and construction of each subject, it is required that each ideological and political teaches should strengthen the learning of theory of Marxism, can master and understand some latest research achievements of Marxism and improve their theoretical quality, teaching ability and teaching skill in the continuous practice, but due to too heavy teaching burden for teachers, there is a certain contradiction between the teachers' task and the construction of scientific research.

\section{Problems existing in teachers themselves}

Due to the development and reform of economic system in China, some public ownerships of the means of production established on the basis of Marxism have been seriously shocked in many aspects. The reform of economic system has brought diversified concepts to the developing China. In such a situation, teachers of ideological and political theory course in many universities have not deeply learned and discussed the theoretical knowledge of Marxism actually, causing many problems. Some ideological and political teachers even use the concept of idealism to replace the concept of Marxism and lead the students to believe in the theism, and such transformation will directly influence the normal implementation of ideological and political education course. At the same time, because of the enlarging of gap between the rich and the poor unconsciously, the benefit demand of people in various levels of the society has been larger and larger, and some ideological and political theory course teachers believe individualism and money worship blindly. The ideology of university students is influenced by the ideological diversification, to cultivate the university students into the 
successors of the cause of nation, the ideological and political course teachers should continuously improve their own ideological and moral quality and teaching ability. If the ideological and political teachers themselves believe in the idealism, how can the students build the correct ideological and political consciousnesses?

\section{Strategy to construct the ideological and political education of university students}

\section{Setting up school of Marxism}

In recent years, many universities have set up school of Marxism, but just from quantity, this is far from enough. Professor Chen Zhan'an of Peking University proposes to further set up the secondary institution of school of Marxism, which is not only beneficial for various subjects and the teacher team, but also beneficial for the construction of ideological and political theory course from many aspects. In addition, some other ideological and political education ideas can further reflect the nature of universities of socialism with Chinese characteristics. Therefore, it is quite necessary and also urgent to set up school of Marxism in various universities of China.

\section{Improving the students' interest in learning}

In recent years, while carrying out the ideological and political theory course in universities, China has improved the teachers' skills in many aspects. We should continuously summarize experience and lesson in continuous development, emphasize the implementation of ideological and political education course in China. We should not only strengthen the emphasis on the teaching ability and teaching level, but also emphasize the cultivation of the teachers' scientific research level. While improving the skills and quality of the ideological and political education teachers, we should also strictly manage the appointment of teachers, establish the strict appointment system and advocate that the teachers should strengthen learning awareness and build the awareness of life-time learning during their occupation. The teachers of ideological and political theory course should not only fully realize their own responsibility consciousness, but also should convey the contents in books to the students, so that the students can master and apply the knowledge. This requires the teachers to apply scientific teaching method and continuously improve their language organization ability and thinking ability in the process of teaching, so that their way of teaching can be accepted and loved by the students. If the students have a strong interest in the learning of ideological and political course, they will achieve the learning effect. The ideological and political education teachers should improve the students' interest in learning ideological and political theory course from many aspects, strengthen their understanding and mastering to the ideological and political course, and apply the knowledge learned to solve the realistic problem in reality.

\section{Updating the preparation method of teaching material contents}

To fully consider the scientific property of Marxism, the contents of ideological and political education teaching materials in universities are somewhat the same with those in the middle school. From the aspect of teaching contents, the ideological and political education theory course in universities more emphasize the deep learning of theoretical course, and some basic course contents are deeply learned and discussed. In order to help the students understand the contents they learn more easily, it is possible to add some classic discourses of Marxism in the teaching contents. In this way, in the spare time after class, the students can carry out deep discussion according to these contents. This cannot only strengthen the students' deep understanding and analysis to the knowledge learnt, but can also help the students apply the thinking of Marxism to solve the problem encountered reality. At the same time, it is also required to timely update the contents of teaching materials, which should keep up with the times.

\section{Effective combination of traditional way of teaching with modern way of teaching}

Strengthen the work of ideological and political education and deeply research some case teaching and practical teaching, and this can help the students experience and learn knowledge in practice, and the truth of knowledge can also be reflected in practice, and this can deepen the students' learning and understanding to the class knowledge. In the practical teaching, arouse the students' thinking from many aspects, so that they can understand that the contents in ideological and political education can 
be better understood but not mechanically recited. However, in the process of practice, teachers should continuously strengthen the guidance of theoretical knowledge, the ideological concept of Marxism can be formed only upon the continuous learning of students, and some teaching contents can be understood by the students only upon the explanation of teachers. With the rapid development of times, the traditional way of education obviously cannot make students understand and master the concept of Marxism and it is required to improve and innovate the way of education on the basis of applying the way of "infusion" and combine the traditional way of education with the modern way of education, so as to improve the effectiveness of ideological and political course from many aspects.

\section{Adopting many examination methods}

The most effective way to inspect the teaching achievement is examination, and it is also a main approach to improve the students' ideological and political education. The main assessment contents of ideological and political theory course are not only the examination to the students' master degree, but also to examine whether the students have changed their learning thinking after learning the ideological and political theory course and whether apply the knowledge learnt to solve the actual problems. Because of collective teaching, examination has become the only way for teachers to limit the students. However, upon investigation, it is found that such way cannot drive the students' interest in learning ideological and political education course, but on the contrary increases their boring. Therefore, we must start from the actuality of the ideological and political theory course, and adopt a series of examination forms, so that the students can comprehensively understand the knowledge of ideological and political course and apply the knowledge learnt repeatedly to solve the actual problems. It is possible to propose some theoretical knowledge and practical knowledge to students through essay or class quiz, so as to understand the students' mastering of the knowledge learnt, and meanwhile, it is also examine the students' learning attitude in the application of such way, so as to further improve their interest in the ideological and political theory course.

\section{Conclusion}

In the continuous reform, certain achievements have been made in the ideological and political education work, but there are still many problems. The diversity of some ways of teaching is continuously emphasized, so that the students can actively participate in the process of teaching and continuously improve their self-learning consciousness and ability, and link with the effectiveness of ideological and political education really in way of teaching, so as to ensure that the innovative way of ideological and political theory course can be applied in class.

\section{References}

[1] Song Jian, Thought on Construction of Marxism Theory Subject and Ideological and Political Theory Course, Ideological Theory Education, 2012,(23).

[2] Li Liang, Exploration Course and Basic Experience of Teaching Material Construction of Ideological and Political Theory Course in Universities since the Founding of PRC, Ideological Theory Education Guide, 2010,(01).

[3] Chen Zhan'an Thought on Further Strengthening Construction of Teachers of Ideological and Political Theory Course-On the 5th Anniversary of Implementation of "05 Plan” of Political Ideological Course, Ideological Theory Education, 2010 (11)

[4] Chen Zhan'an Thought on Further Strengthening Construction of Teachers of Ideological and Political Theory Course-On the 5th Anniversary of Implementation of "05 Plan" of Political Ideological Course, Ideological Theory Education, 2010 (11)

[5] Yang Ruisen, Re-thinking on Relation between Ideological and Political Theory Education in Universities and Construction of Marxism, Theory Course Ideological Theory Education Guide, 2009,(09) . 
[6] Zeng Xuelong, Discussion on New Model of Ideological and Political Theory Course of “Combing Knowledge with Deed, Penetrating Morality into Beauty, 2009,(25) . 